\title{
ANTIOXIDANT AND INHIBITION OF $\alpha$-AMYLASE ACTIVITIES OF PAPASAN (Coccinia grandis (L.) Voigt) LEAVES AND BELIMBING WULUH (Averrhoa bilimbi L.) FRUITS COMBINED INFUSIONS
}

\author{
I. M. W. A. Putra ${ }^{1 *}$, O. T. Ate ${ }^{2}$, I G. A. W. Kusumawati ${ }^{2}$, N. W. Nursini ${ }^{2}$ \\ ${ }^{1}$ Department of Biology, University of Dhyana Pura, Badung, Bali, Indonesia \\ ${ }^{2}$ Department of Nutrition Science, University of Dhyana Pura, Badung, Bali, Indonesia \\ *Email: wisnuadhiputra@undhirabali.ac.id
}

\begin{abstract}
ABSTRAK
Aktivitas famakologi suatu herbal dapat ditingkatkan dengan menggabungkannya dengan herbal lain. Penelitian ini bertujuan untuk membuat infusa herbal dari kombinasi daun papasan (Coccinia grandis (L.) Voigt) dan buah belimbing wuluh (Averrhoa bilimbi L.). Sifat antioksidan dan penghambatan enzim $\alpha$-amilase infusa tersebut kemudian diuji. Campuran serbuk daun papasan dan buah belimbing wuluh dengan perbandingan massa 1:3, 1:1, dan 3:1 diseduh dengan $100 \mathrm{~mL}$ air mendidih selama 5 menit. Campuran tersebut kemudian disaring dan dibiarkan dingin. Uji aktivitas antioksidan dilakukan dengan menggunakan 2,2-difenil-1pikrilhidrazil (DPPH) sebagai sumber oksidan dan uji penghambatan aktivitas $\alpha$-amilase dilakukan dengan menggunakan metode pati-iodin. Hasil uji aktivitas antioksidan menggunakan metode DPPH menunjukkan bahwa sampel dengan kombinasi rasio $1: 1$ memiliki nilai $\mathrm{IC}_{50}$ terendah $(2,56 \pm 0,29 \mathrm{mg} / \mathrm{mL}) \mathrm{yang}$ mengindikasikan aktivitas penangkapan radikal terkuat. Penghambatan aktivitas $\alpha$-amilase tertinggi ditemukan pada sampel dengan rasio $3: 1\left(\mathrm{IC}_{50}=0,75 \pm 0,45 \mathrm{mg} / \mathrm{mL}\right)$. Namun, secara umum semua kombinasi rasio daun papasan dan buah belimbing wuluh memiliki potensi yang baik sebagai minuman sehat.
\end{abstract}

Kata kunci: kombinasi herbal, minuman kesehatan, antioksidan, penghambatan $\alpha$-amilase

\section{ABSTRACT}

The pharmacology activity of an herb can be increased by combining it with other herbs. This study aimed to make herbal infusions from the combination of papasan (Coccinia grandis (L.) Voigt) leaves and belimbing wuluh (Averrhoa bilimbi L.) fruits. Antioxidant and inhibition properties of $\alpha$-amylase enzymes were then tested. A mixture of Coccinia grandis (L.) Voigt leave and Averrhoa bilimbi L. fruit powder with a mass ratio of 1:3, 1:1, and 3:1 was brewed with $100 \mathrm{~mL}$ of boiling water for 5 minutes. The mixture was then filtered and allowed to cool. The antioxidant activity test was carried out using 2,2-diphenyl-1-picrylhydrazyl (DPPH) as an oxidant source and the $\alpha$-amylase activity inhibition test was performed using the starch-iodine method. The results of the antioxidant activity test using the DPPH method showed that samples with a 1:1 combination ratio had the lowest $\mathrm{IC}_{50}$ value $(2.56 \pm 0.29 \mathrm{mg} / \mathrm{ml})$ which indicated the strongest radical scavenging activity. The highest inhibition of $\alpha$-amylase activity was found in the sample with a ratio of $3: 1\left(\mathrm{IC}_{50}=0.75 \pm 0.45 \mathrm{mg} / \mathrm{mL}\right)$. However, in general all the combination ratios of Coccinia grandis (L.) Voigt leaves and Averrhoa bilimbi L. fruits had good potential as healthy beverages.

Keywords: herbal combination, healthy beverages, antioxidant, inhibition of $\alpha$-amylase

\section{INTRODUCTION}

Type 2 Diabetes mellitus (T2DM) is a degenerative disease characterized by chronic hyperglycemia due to the body's resistance to insulin (Sing et al., 2016). Globally, T2DM is a disease that attacks more than 400 million people worldwide, by 2040 it is estimated that more than 640 million people with diabetes worldwide (Marín-Peñalver et al., 2016). Treatment of patients with T2DM is usually done by administering insulin and drugs such as sulfonylurea, metformin, and meglitinide (Gómez-Huelgas et al., 2018). Despite considerable progress in treating diabetes with hypoglycemic drugs, the search for new drugs continues due to synthetic drugs have limitations such as nausea, vomiting, diarrhea, 
fever, hypoglycemia and, decreased appetite (Arumugam et al., 2013). Due to the side effects of these drugs, treatment of T2DM has shifted to the use of herbal ingredients. Herbal medicines contain active ingredients that are either in the extraction form of one plant or other plant material or a combination of plants (Chawla et al., 2013).

Cocciniagrandis (L.) Voigt has been widely studied in recent years as a natural antidiabetic. This plant showed significant insulinotropic properties by stimulating an increase in insulin and can reduce blood sugar levels in streptozotocin-induced mice that were almost the same as the standard drug action metformin (Mohammed et al., 2016). Cocciniagrandis (L.) Voigt also plays a role in regeneration of $\beta$ cells in the pancreas and can reduce the risk of complications such as dyslipidemia and oxidative stress (Attanayake et al., 2015).Although this plant has been proven as a good antidiabetic, however, its ability is still relatively low when compared with synthetic drugs. Attanayake et al. (2013) showed that the antidiabetic ability of Cocciniagrandis (L.) Voigt leaf extract at a dose of $0.75 \mathrm{~g} / \mathrm{kg}$ in diabetic rats was still lower compared to the drug glibenclamide.

Increasing the antidiabetic activity of an herbal can be done by combining it with other herbs with the same activity. Averrhoabilimbi $\mathrm{L}$. is one of the medicinal plants that has the potential as an antidiabetic. This plant generally contains flavonoids, steroids, triterpenoids, glycosides, proteins, fats, calcium, iron, vitamins A, B, and C (Anggraini et al., 2016). Antioxidants in Averrhoabilimbi L. fruit showed significant results in reducing blood glucose levels oxidative stress in streptozotocin-induced mice (Kurup and Mini, 2017).This research was conducted to make infusions from the combination of Cocciniagrandis (L.) Voigt leaves and Averrhoabilimbi L. fruits in various mass ratio. Infusions were then tested for the antioxidant activity and inhibition of $\alpha$-amylase enzyme activity.

\section{MATERIALS AND METODS}

\section{Materials}

Papasan (Cocciniagrandis (L.) Voigt) leaves and belimbing wuluh (Averrhoabilimbi L.) fruits were collected from herbal garden in
(University of Dhyana Pura) in Pebruary 2019 and were determined in Pharmacognosy Laboratory, Pharmaceutical Biology Department, Faculty of Pharmacy, Universitas Gajah Mada, Indonesia. Ethanol and phosphate buffer $\mathrm{pH} 7.4$ were purchased from Merck. 2,2-diphenyl-1-picrylhydrazyl (DPPH), $\alpha$ amylase, potassium iodate, starch, were purchased from Sigma Aldrich. Acarbose (Glucobay) was purchased from PT. Bayer Indonesia.

\section{Instruments}

UV-Vis spectrophotometer (Thermo Scientific GENESYS 10S) was used to measure the absorbance of the samples. Other instruments used in this research were: analytical balance (Ohaus Pioneer PA214), blender (Philips), oven (Memmert UN 75), portable stove (Cosmos CGS-123 P), micropipette (Socorex Acura Manual 825), porcelain cup, and laboratory glassware.

\section{Preparation of herbal infusions}

In this step, we used fresh Cocciniagrandis (L.) Voigt leaves and Averrhoabilimbi L. fruits. These materials were washed with running water and allowed to dry at room temperature. The leaves and fruits were then dried in the oven at $50^{\circ} \mathrm{C}$ for 3 days. The dry materials were crushed using a blender and sifted to get a fine powder. The powder was infused at various mass ratio (1:0, $3: 1,1: 1,1: 3$, and $0: 1)$ and various powder masses (1-5 g). Infusing process was done using $100 \mathrm{~mL}$ of hot water at $100^{\circ} \mathrm{C}$ for 5 minutes. The mixture was filtered and allowed to stand at room temperature.

\section{Antioxidant activity test}

Antioxidant activity test using the DPPH method was carried out based on the method delivered by Attanayake et al. (2016). An amount of $20 \mu \mathrm{l}$ of infusion sample was diluted in distilled water $(480 \mu \mathrm{L})$ followed by the addition of $2.0 \mathrm{~mL}$ of DPPH solution in ethanol $(0.004 \%)$. The mixture was shaken strongly then allowed to stand at room temperature for 30 minutes. Ethanol was used as a blank sample. The absorbance of the sample was measured at a wavelength of 517 nm using a UV-Vis spectrophotometer. Antioxidant activity was expressed as \% 
inhibition and $\mathrm{IC}_{50}(\mathrm{mg} / \mathrm{mL})$. The value of $\%$ inhibition can be calculated using the formula:

$$
\% \text { Inhibition }=\frac{A_{c}-A_{s}}{A_{c}} \times 100
$$

where $\mathrm{A}_{\mathrm{c}}=$ absorbance of the control, $\mathrm{A}_{\mathrm{s}}=$ absorbance of the sample. The $\mathrm{IC}_{50}$ value $(\mathrm{mg} / \mathrm{mL})$ was obtained from the plot of $\%$ inhibition against sample concentration. All tests were carried out in triplicate and the results were expressed as the mean \pm standard error of the mean (SEM).

\section{Inhibition of $\alpha$-amylase activity test}

The $\alpha$-amylase inhibitory activity test was carried out by the iodine-starch method (Neagu et al., 2018). Sample was taken as much as $30 \mu \mathrm{L}$ and mixed with $50 \mu \mathrm{L}(400$ $\mu \mathrm{L} / \mathrm{mL})$ starch in phosphate buffer $(0.25 \mathrm{M}$; $\mathrm{pH}$ 7.0). After 30 minutes of incubation at $37^{\circ} \mathrm{C}, 10 \mu \mathrm{l} \alpha$-amylase $(50 \mu \mathrm{g} / \mathrm{mL}$ in phosphate buffer) was added to the mixture, followed by adding $10 \mu \mathrm{l}$ of $0.25 \mathrm{M}$ phosphate buffer. As much as $50 \mu \mathrm{l}$ of iodine solution $(0.01 \mathrm{~N})$ and $1300 \mu \mathrm{L}$ distilled water were added to the mixture. Absorbance measurements were carried out at a wavelength of $660 \mathrm{~nm}$. The $\alpha$ amylase inhibitory activity was expressed as $\%$ inhibition and $\mathrm{IC}_{50}(\mathrm{mg} / \mathrm{mL})$. The results of the study were expressed as the mean \pm standard error of the mean (SEM) and the experiment was carried out in at least three replications. Significant differences were assessed by the normality test and then followed by the analysis of variance (ANOVA) test. If there was a significant difference $(p<0.05)$, it continued with the Tukey test. This statistical analysis was performed using SPSS v.24 software (IBM).

\section{RESULT AND DISCUSSION}

\section{Antioxidant activity}

Antioxidants are chemicals that have an ability to delay or inhibit cell damage caused by free radicals. Free radicals can exist in our body due to environmental exposure or various metabolic processes. In health care, antioxidants act as free radical scavengers and help our body to prevent various chronic diseases and premature aging (Tuyen et al., 2016). It can be seen from Table 1 that all samples had good antioxidant activities in order to inhibit DPPH free radicals.

Table 1. Antioxidant Activity of Infusions at Various Mass Ratios and Amount of Powdered Plant Samples

\begin{tabular}{|c|c|c|c|c|c|c|}
\hline \multirow{2}{*}{ Samples } & \multirow{2}{*}{ Ratio } & \multicolumn{5}{|c|}{ Antioxidant Activity (\% inhibition) } \\
\hline & & $1 \mathrm{~g}$ & $2 \mathrm{~g}$ & $3 \mathrm{~g}$ & $4 \mathrm{~g}$ & $5 \mathrm{~g}$ \\
\hline$\overline{\mathrm{CG}}$ & $1: 0$ & $36.95 \pm 0$. & $.75 \pm 0.16$ & $39.98 \pm 0.19^{b c}$ & $41.06 \pm 0.16$ & $45.73 \pm 0.34^{\text {efg }}$ \\
\hline $\mathrm{CG}+\mathrm{A}$ & : & $48.46 \pm 0.2$ & $49.43 \pm 0.39^{\text {fgh }}$ & $49.88 \pm 0.12^{\mathrm{fgh}}$ & $52.08 \pm 0.09^{\text {ghi }}$ & $52.50 \pm 0.26^{\mathrm{hij}}$ \\
\hline $\mathrm{CG}+\mathrm{A}$ & $1: 1$ & $47.75 \pm 0.2$ & $49.32 \pm 0.34^{\mathrm{fgh}}$ & $51.08 \pm 0.20^{\mathrm{ghi}}$ & $51.45 \pm 0.44^{\text {ghi }}$ & $54.11 \pm 1.83^{\mathrm{ijk}}$ \\
\hline $\mathrm{CQ}$ & $1: 3$ & $32.54 \pm 1$ & $37.96 \pm 1.58^{\mathrm{b}}$ & $42.56 \pm 0.16^{\text {cde }}$ & $49.62 \pm 0.03^{\text {ghi }}$ & $56.50 \pm 0.39^{\mathrm{jk}}$ \\
\hline $\mathrm{AB}$ & $0: 1$ & $44.65 \pm 0.08^{\mathrm{def}}$ & $50.97 \pm 0.35^{\text {hij }}$ & $57.28 \pm 0.84^{\mathrm{k}}$ & $56.57 \pm 1.88^{\mathrm{jk}}$ & $49.10 \pm 0.17^{\text {ghi }}$ \\
\hline
\end{tabular}

Antioxidant activity values were represented in the mean \pm standar error of the mean $(n=3)$. Different letters indicate significant difference based on Tukey test $(\mathrm{P}<0.05)$. CG: Cocciniagrandis (L.) Voigt, AB: Averrhoabilimbi L.

The addition of DPPH resulted in a purple discoloration in ethanol and sample solutions due to the presence of electron or hydrogen donors to become more stable molecules (Rahman et al., 2014). Color fading reduced the absorbance value of light on the UV-Vis spectrophotometer. Thus, the lower the absorbance value, the higher the antioxidant activity owned (Anggraini et al., 2016). Table 1 showed that the antioxidant activity (\% inhibition) of infusions increased when combined with different ratios. This also happened to the sample when the mass of powder increases. The higher the mass of the powder, the higher the \% inhibition of the samples. 
Antioxidant and Inhibition Of A-Amylase Activities of Papasan (Coccinia Grandis (L.) Voigt) Leaves and Belimbing Wuluh (Averrhoa Bilimbi L.) Fruits Combined Infusions

(I. M. W. A. Putra, O. T. Ate, I G. A. W. Kusumawati, N. W. Nursini)

Table 2. Antioxidant and Inhibition of $\alpha$-Amylase Activity $\left(\mathrm{IC}_{50}\right)$ Values of Infusions

\begin{tabular}{cccc}
\hline Samples & Ratio & $\begin{array}{c}\text { Antioxidant Activity, } \mathrm{IC}_{50} \\
(\mathrm{mg} / \mathrm{mL})\end{array}$ & Inhibition of $\alpha$-Amylase, $\mathrm{IC}_{50}(\mathrm{mg} / \mathrm{mL})$ \\
\hline $\mathrm{CG}$ & $1: 0$ & $7.78 \pm 0.30^{\mathrm{d}}$ & $2.03 \pm 0.30^{\mathrm{abc}}$ \\
$\mathrm{CG}+\mathrm{AB}$ & $3: 1$ & $2.73 \pm 0.22^{\mathrm{ab}}$ & $0.75 \pm 0.45^{\mathrm{ab}}$ \\
$\mathrm{CG}+\mathrm{AB}$ & $1: 1$ & $2.56 \pm 0.29^{\mathrm{ab}}$ & $4.14 \pm 0.10^{\mathrm{ab}}$ \\
$\mathrm{CG}+\mathrm{AB}$ & $1: 3$ & $4.04 \pm 0.02^{\mathrm{b}}$ & $3.23 \pm 0.21^{\mathrm{de}}$ \\
$\mathrm{AB}$ & $0: 1$ & $1.89 \pm 0.59^{\mathrm{a}}$ & $0.32 \pm 0.12^{\mathrm{a}}$ \\
Acarbose* $^{\mathrm{a}}$ & - & - & $3.86 \pm 0.07^{\mathrm{b}}$
\end{tabular}

$\mathrm{IC}_{50}$ values were represented in the mean \pm standar error of the mean $(\mathrm{n}=3)$. Different letters indicate significant difference based on Tukey test $(\mathrm{P}<0.05)$. CG: Cocciniagrandis (L.) Voigt, AB: Averrhoabilimbi L, IC $\mathrm{C}_{50}$ : Inhibitory Concentration, *: positive control.

Based on the $\mathrm{IC}_{50}$ calculation results (Table 2), in all combination, it was found that the $\mathrm{CG}+\mathrm{AB}$ sample $(1: 1)$ had the lowest $\mathrm{IC}_{50}$ value $(2.56 \pm 0.29 \mathrm{mg} / \mathrm{mL})$, which means that this combination had the highest antioxidant activity value. Statistical analysis using ANOVA $(p<0.05)$ showed significantly different values for each sample. The results of further tests using the Tukey test showed that some samples had differences in antioxidant activity. The phenolic and flavonoid compounds can act as an antioxidant in counteracting free radicals and reducing oxidative stress (Meenatchiet al., 2017; Suluvoyet al., 2017). In addition, these compounds have a high scavenging ability related to the hydroxyl groups present in these compounds (Suluvoyet al., 2017). This was supported by research conducted by Jain et al. (2011), which showed that the combination of green tea and polyherbalhadhigh antioxidant activity in terms of capturing free radicals.

\section{Inhibition of $\boldsymbol{\alpha}$-amylase activity}

Table 3 shows the results of $\alpha$-amylase inhibition test using the iodine-starch method. All infusion samples had the ability to inhibit the performance of the $\alpha$-amylase enzyme. In general, the combination of $\mathrm{CG}$ and $\mathrm{AB}$ gave an increase in the value of $\%$ inhibition. Compared to conventional medicine (a carbose), the infusions still had a higher \% inhibition value. The value of $\%$ inhibition also increased with the increase in the amount of powder, indicating that more active compounds were extracted. Among all these combinations, the sample which had the highest $\alpha$-amylase enzyme inhibitory activity was $\mathrm{CG}+\mathrm{AB}$ (3:1) with an $\mathrm{IC}_{50}$ value of $0.75 \pm 0.45 \mathrm{mg} / \mathrm{mL}$ (Table 2).

Table 3.Inhibition of $\alpha$-Amylase Activity of Infusions at Various Mass Ratios and Amount of Powdered Plant Samples

\begin{tabular}{|c|c|c|c|c|c|c|}
\hline \multirow{2}{*}{ Samples } & \multirow{2}{*}{ Ratio } & \multicolumn{5}{|c|}{ Inhibition of $\alpha$-Amylase Activity ( $\%$ inhibition) } \\
\hline & & $1 \mathrm{~g}$ & $2 \mathrm{~g}$ & $3 \mathrm{~g}$ & $4 \mathrm{~g}$ & $5 \mathrm{~g}$ \\
\hline $\mathrm{CG}$ & 1:0 & $37.68 \pm 2.34^{\mathrm{abc}}$ & $41.57 \pm 8.47^{\mathrm{abcd}}$ & $70.49 \pm 0.15^{\mathrm{hi}}$ & $73.55 \pm 0.92^{i}$ & $74.49 \pm 0.30^{\mathrm{i}}$ \\
\hline $\mathrm{CG}+\mathrm{AB}$ & $3: 1$ & $53.09 \pm 4.18^{\text {cdefghi }}$ & $51.07 \pm 1.53^{\text {bcdefg }}$ & $62.90 \pm 1.89^{\text {fghi }}$ & $67.60 \pm 0.09^{\text {fghi }}$ & $70.80 \pm 0.51^{\mathrm{hi}}$ \\
\hline $\mathrm{CG}+\mathrm{AB}$ & $1: 1$ & $33.57 \pm 0.48^{\mathrm{ab}}$ & $38.27 \pm 1.61^{\mathrm{abc}}$ & $42.10 \pm 0.48^{\text {abcde }}$ & $53.30 \pm 0.94^{\text {cdefgh }}$ & $52.47 \pm 0.42^{\text {cdefgh }}$ \\
\hline $\mathrm{CG}+\mathrm{AB}$ & $1: 3$ & $30.37 \pm 2.51^{\mathrm{a}}$ & $29.78 \pm 0.77^{\mathrm{a}}$ & $50.31 \pm 1.64^{\text {bcdef }}$ & $57.68 \pm 2.23^{\text {defghi }}$ & $69.45 \pm 0.13^{\mathrm{ghi}}$ \\
\hline $\mathrm{AB}$ & $0: 1$ & $60.19 \pm 6.57^{\text {efghi }}$ & $64.37 \pm 7.97^{\text {eghi }}$ & $68.89 \pm 2.87^{\mathrm{ghi}}$ & $62.97 \pm 7.18^{\text {fghi }}$ & $73.97 \pm 0.88^{\mathrm{i}}$ \\
\hline Acarbose & - & $32.39 \pm 0.15^{\mathrm{a}}$ & $36.84 \pm 0.18^{\mathrm{b}}$ & $42.79 \pm 1.43^{\mathrm{c}}$ & $53.22 \pm 0.35^{\mathrm{d}}$ & $56.22 \pm 0.09^{\mathrm{d}}$ \\
\hline
\end{tabular}

Inhibition of $\alpha$-amylase activity values were represented in the mean \pm standar error of the mean $(n=3)$. Different letters indicate significant difference based on Tukey test $(\mathrm{P}<0.05)$. CG: Cocciniagrandis (L.) Voigt, AB: Averrhoabilimbi L.

One of the enzymes that plays an important role in the breakdown of oligosaccharides and disaccharides into monosaccharides so that they are ready to be 
absorbed is the $\alpha$-amylase enzyme. Diabetes mellitus treatment strategies related to carbohydrate absorption is by inhibiting $\alpha$ amylase enzyme. An enzyme inhibitory activity test is an efficient way to decrease postprandial blood glucose levels (Kazeemet $a l ., 2013)$. Determination of $\alpha$-amylase enzyme inhibitory activity is characterized by a decrease in blue color intensity in the iodinestarch complex due to the hydrolysis of starch by the $\alpha$-amylase (Wardani, 2017). Inhibition of $\alpha$-amylase contributes to improve the symptoms of T2DM and delay glucose absorption due to slow digestion of starch (Jemaaet al., 2017).

Damage to the $\beta$-cells occurs through several processes simultaneously, namely through oxidation of sulfhydryl groups and the formation of free radicals that can attack the components of the cell, causing cells damage (Kurup and Mini, 2017).Herbs have an ability to regenerate pancreatic $\beta$-cells, release insulin into the blood, and reduce the occurrence of insulin resistance (Attanayakeet al., 2015). Flavonoid and phenolic compounds in CG leaves and $\mathrm{AB}$ fruit function can act as antioxidants and antidiabetic that can increase insulin secretion, use of glucose by adipose or muscle tissue, inhibit glucose absorption in the intestine, and store glucose in the liver in the form of glycogen(Attanayakeet al., 2013; Kurup and Mini, 2017). The results of the analysis using ANOVA $(\mathrm{p}<0.05)$ showed significantly different values for each sample. The results of further tests using the Tukey test showed that some samples had significant $\alpha$ amylase inhibitory activity differences.

The inhibitory activity of $\alpha$-amylase enzymes from the combination of CG leaves and $\mathrm{AB}$ fruits was lower than that of the individual samples. Combining herbal ingredients can cause different interactions and effects due to the number of compounds they have does not always have a synergistic effect (Nedamaniet al., 2015). Antagonistic occurs because of the presence of several components in plants that do not interact with each other when combined (Okokonet al., 2013). Acarbose was used as a positive control in the study with an $\mathrm{IC}_{50}$ value of $3.86 \pm 0.07 \mathrm{mg} / \mathrm{mL}$ The samples had better $\alpha$-amylase inhibitory activity compared to positive control and could be used for the treatment of T2DM. Similar study shows the combination of sea lavender and green tea showed the $\alpha$-amylase enzyme inhibitory activity better than the acarbose (Rodrigues et al., 2019). The combination of Vernoniaamygdalina, Ocimumgratissimum, and Gongronemalatifolium extracts showed significant antidiabetic activity in alloxan induced diabetic rats (Okokonet al., 2013). In addition, the combination of Astragali radix and Rehmanniae radix with a ratio of $2: 1$ can significantly treat diabetic foot ulcers because it can stimulate fibroblast proliferation and inhibit cell inflammation (Lau et al., 2012).

\section{CONCLUSIONS}

In general, the combination of papasan leave (CG) and belimbing wuluh fruit (AB) infusions had great potential for antioxidant and $\alpha$-amylase inhibition. This research has provided a basis for continuing research related to the antidiabetic activity of herbal combination extracts. Further testing to animals is needed to understand the mechanism of action of this combination.

\section{REFERENCES}

Anggraini, T., Febrianti, F., Aisman, and Ismanto, S. D. 2016. Black tea with AverrhoaBilimbi L extract: A healthy beverage. Agriculture and Agricultural Science Procedia. 9: 241-252.

Attanayake, A. P., Jayatilaka, K. A. P. W., Mudduwa, L. K. B., and Pathirana, C. 2016. In vivoantihyperlipidemic, antioxidative effects of cocciniagrandis (L.) Voigt (cucurbitaceae) leaf extract: an approach to scrutinize the therapeutic benefits of traditional Sri Lankan medicines against diabetic complications. International Journal of Pharmaceutical Sciences and Research. 7(10): 3949-3958.

Attanayake, A. P., Jayatilaka, K. A. P. W., Pathirana, C., andMudduwa, L. K. B. 2013. Efficacy and toxicological evaluation of Cocciniagrandis (Cucurbitaceae) extract in male Wistar rats. Asian Pacific Journal of Tropical Disease. 3(6): 460-466.

Attanayake, A. P., Jayatilaka, K. A. P. W., Pathirana, C., and Mudduwa, L. K. B. 2015. Antihyperglycemic activity of Cocciniagrandis (L.) Voigt in streptozotocin induced diabetic rats. 
Indian Journal of Traditional Knowledge. 14(3): 376-381.

Arumugam, G., Manjula, P., and Paari, N. 2013. A review: Anti diabetic medicinal plants used for diabetes mellitus. Journal of Acute Disease. 2(3):196-200.

Chawla, R., Thakur, P., Chowdhry, A., Jaiswal, S., Sharma, A., Goel, R., et al. 2013. Evidence based herbal drug standardization approach in coping with challenges of holistic management of diabetes: a dreadful lifestyle disorder of $21^{\text {st }}$ century. Journal of Diabetes \& Metabolic Disorders. 12(1): 35.

Gómez-Huelgas, R., Gómez Peralta, F., RodríguezMañas, L., Formiga, F., PuigDomingo, M., Mediavilla Bravo, J. J.2018. Treatment of type 2 diabetes mellitus in elderly patients. RevistaClínica Española. English Edition. 218(2): 74-88.

Jain, D. P., Pancholi, S. S., Patel, R. 2011. Synergistic antioxidant activity of green tea with some herbs. Journal of Advanced Pharmaceutical Technology and Research. 2(3): 177-183.

Jemaa, H. B., Jemia, A. B., Khlifi, S., Ahmed, H. B., Slama, F. B., Benzarti, A., et al. 2017. Antioxidant activity and $\alpha$-amylase inhibitory potential of Rosa canina L. African Journal of Traditional, Complementary and Alternative Medicines.14(2): 1-8.

Kazeem, M. I., Adamson, J. O., and Ogunwande, I. A. 2013. Modes of inhibition of $\alpha$-amylase and $\alpha$-glucosidase by aqueous extract of MorindalucidaBenth Leaf. BioMed Research International. 2013: 1-6.

Kurup, S. B. and Mini, S. 2017.Averrhoabilimbi fruits attenuate hyperglycemia-mediated oxidative stress in streptozotocin-induced diabetic rats. Journal of Food and Drug Analysis. 25(2): 360-368.

Lau, K-M., Lai, K-K., Liu, C-L., Tama, J. CW., To, M-H., Kwok, H-F., et al. 2012. Synergistic interaction between Astragali radix and Rehmanniae radix in a Chinese herbal formula to promote diabetic wound healing. Journal of Ethnopharmacology. 141: 250-256.

Marín-Peñalver, J. J., Martín-Timón, I., Sevillano-Collantes, C., and delCañizoGómez, F. J. 2016. Update on the treatment of type 2 diabetes mellitus. World Journal of Diabetes. 7(17): 354-95.

Meenatchi, P., Purushothaman, A., and Maneemegalai, S. 2017. Antioxidant, antiglycation and insulinotrophic properties of Cocciniagrandis (L.) in vitro: Possible role in prevention of diabetic complications. Journal of Traditional and Complementary Medicine. 7(1): 54-64.

Mohammed, S. I., Chopda, M. Z., Patil, R. H., Vishwakarma, K. S., andMaheshwari, V. L. 2016. In vivo antidiabetic and antioxidant activities of Cocciniagrandis leaf extract against streptozotocin induced diabetes in experimental rats. Asian Pacific Journal of Tropical Disease. 6(4):298-304.

Neagu, A., Radu, G. L., Albu, C., andPaun, G. 2018. Antioxidant activity, acetylcholinesterase and tyrosinase inhibitory potential of Pulmonariaofficinalis and Centariumumbellatum extracts. Saudi Journal of Biological Sciences. 25(3): 578-585.

Nedamani, E. R, Mahoonak, A. S., Ghorbani, M., and Kashaninejad M. 2015. Evaluation of antioxidant interactions in combined extracts of green tea (Camellia sinensis), rosemary (Rosmarinusofficinalis) and oak fruit (Quercusbranti). Journal of Food Science Technology. 52(7): 4565-4571.

Okokon, J. E., Umoh, U. F., Ekpo, B. A. J., and Etim, E. I. 2013.Antidiabetic study of combined extracts of Vernoniaamygdalina,

Ocimumgratissimum, and Gongronemalatifolium on alloxaninduced diabetic rats. Journal of Natural Pharmaceuticals. 4(1): 28-31.

Rahman, M. M., Habib, M. R., Hasan, M. A., Al Amin, M., Saha, A., and Mannan, A. 2014. Comparative assessment on in vitro antioxidant activities of ethanol extracts of Averrhoabilimbi, Gymnemasylvestre and Capsicum frutescens. Pharmacognosy Research. 6(1): 36-41.

Rodrigues, M. J., Oliveira, M., Neves, V., Ovelheiroa, A., Pereiraa, C. A., Neng, N. R., et al. 2019. Coupling sea lavender (LimoniumalgarvenseErben) and green tea (Camellia sinensis (L.) Kuntze) to produce an innovative herbal beverage 

and Belimbing Wuluh (Averrhoa Bilimbi L.) Fruits Combined Infusions (I. M. W. A. Putra, O. T. Ate, I G. A. W. Kusumawati, N. W. Nursini)

with enhanced enzymatic inhibitory properties. South African Journal of Botany. 120: 87-94.

Sing, S., Usman, K., and Banerjee, M. 2016.Pharmacogenetic studies update in type 2 diabetes mellitus. World Journal of Diabetes. 7(15): 302-315.

Suluvoy, J. K., Sakthivel, K. M., Guruvayoorappan, C., and Grace, B. V. M. 2017. Protective effect of Averrhoabilimbi L. fruit extract on ulcerative colitis in wistar rats via regulation of inflammatory mediators and cytokines. Biomedicine \& Pharmacotherapy. 91: 1113-1121.
Tuyen, P. T., Khang, D. T., Minh, L. T., Minh, T. N., Ha, P. T. T., Elzaawely, et al. 2016; Phenolic Compounds and Antioxidant Activity of Castanopsisphuthoensis and Castanopsisgrandicicatricata.

International Letters of Natural Sciences. 55: 77-87.

Wardani, N. A. K. 2017. Enzim $\alpha$-amilase inhibitor padaekstrak air kacangmerah (Phaseolus vulgaris L.) untukpenanggulangan diabetes melitus. JurnalIlmuPangandanHasilPertanian. 1(2): 50-59. 